University of Nebraska - Lincoln

DigitalCommons@University of Nebraska - Lincoln

2003

\title{
Public Knowledge and Perceptions of Black-Tailed Prairie Dogs
}

Berton Lee Lamb

U.S. Geological Survey, Fort Collins, Colorado, USA

Kurt Cline

U.S. Geological Survey, Fort Collins, Colorado, USA

Follow this and additional works at: https://digitalcommons.unl.edu/usgsstaffpub

Part of the Earth Sciences Commons

Lamb, Berton Lee and Cline, Kurt, "Public Knowledge and Perceptions of Black-Tailed Prairie Dogs" (2003). USGS Staff -- Published Research. 38.

https://digitalcommons.unl.edu/usgsstaffpub/38

This Article is brought to you for free and open access by the US Geological Survey at DigitalCommons@University of Nebraska - Lincoln. It has been accepted for inclusion in USGS Staff -- Published Research by an authorized administrator of DigitalCommons@University of Nebraska - Lincoln. 


\section{Public Knowledge and Perceptions of Black-Tailed Prairie Dogs}

\section{BERTON LEE LAMB}

Policy Analysis and Science Assistance Program, Fort Collins Science Center, U.S. Geological Survey, Fort Collins, Colorado, USA

\section{KURT CLINE}

Johnson Controls World Services, Inc. U.S. Geological Survey, Fort Collins, Colorado, USA

Black-tailed prairie dogs (Cynomys ludovicianus) historically occupied an 11 -state region of the United States. We surveyed 1,900 residents (response rate 56\%) of this region to understand citizen knowledge and perceptions about prairie dogs and their management. Those who have direct experience-e.g., those who live very close to prairie dog colonies or know the location of the nearest colony-have higher levels of knowledge. A significantly higher level of knowledge was documented among those who were politically active when compared with the general public. Those who found environmental issues difficult to understand were associated with lower knowledge. People with direct experience were likely to hold negative views, whereas those holding environmentalist values were likely to express positive attitudes toward the species. Although those with higher education reported more knowledge, there was no link between a person's level of knowledge and perceptions of prairie dog management.

Keywords attitudes, Endangered Species Act, environmental education, nongame wildlife, public participation, species management, threatened species

This article is not subject to U.S. copyright law.

We wish to thank our colleagues Phadrea D. Ponds for help with study design and data collection, Natalie Sexton and Ayeisha Brinson for assistance with design, data management, and analysis, Donna Lybecker for help with background research, David Fulton, Brent Steel, and Nicholas P. Lovrich for helpful comments and suggestions, and two anonymous reviewers for comments on an earlier version of this article.

Address correspondence to Berton Lee Lamb, Policy Analysis and Science Assistance Program, Fort Collins Science Center, 2150 Centre Avenue, Building C, Ft. Collins, Colorado. 80526-8118, USA. Fax: (970) 226-9230. E-mail: lee_lamb@usgs.gov 


\section{Introduction}

Prairie dogs have increasingly become a concern for wildlife professionals who must find ways to manage the animals across multiple states and in collaboration with many stakeholders. In 1998, the National Wildlife Federation, Predator Conservation Alliance, and Biodiversity Legal Foundation petitioned the federal government to acknowledge the declining numbers of black-tailed prairie dogs (Cynomys ludovicianus) and recognize their importance to the prairie ecosystem by determining that the species is threatened (Graber \& France, 1998; 64 Federal Register 57 at 14425). Another species of prairie dog (white-tailed, Cynomys leucurus) was petitioned for listing in 2002 (Center for Native Ecosystems, 2002). The management and conservation of prairie dogs is considered by many wildlife researchers to be vital for the effective conservation of a large number of other grassland species (Kotliar, Baker, Whicker, \& Plumb, 1999; Miller, Reading, \& Forest 1996). But studies of specific geographic areas have suggested that there is only limited knowledge of and public support for prairie dog management (Lybecker, Lamb, \& Ponds, 2002).

The question of what people know and what benefits they perceive from management has become more pressing since 2000, when the U.S. Fish and Wildlife Service (USFWS) found that listing the black-tailed prairie dog as threatened was warranted. The USFWS decided to not list the species at that time (pursuant to Section 4(b)(7) of the Endangered Species Act and the USFWS "Listing Priority Guidance" [63 FR 25502]) because delaying the listing would give individual states an opportunity to implement their own protection programs (Hughes, 2000). Indeed, even before the USFWS finding, nine states had moved toward cooperative plans that might afford protection to the species (Hughes, 2000; Van Pelt, 1999). By early 2002, six states had established "clear regulatory authority to limit control by poisoning" (Black-tailed Prairie Dog Conservation Team, 2002, p. 2). Further development of management plans involves complex interactions with the public. We studied residents of the 11-state, short-grass prairie region of the United States to understand what people know about prairie dogs and the benefits they believe may be derived from their management. The objective was to suggest management actions that might enhance public awareness of and involvement in decisions about prairie dogs.

Other researchers have investigated people's knowledge and perceptions of prairie dogs (e.g., Lee \& Henderson, 1989). Reading, Miller, and Kellert (1999) studied residents of two Montana counties. Zinn and Andelt (1999) investigated the perceptions and knowledge of residents of Fort Collins, Colorado. The Wyoming Agricultural Statistics Service (2001) queried farmers and ranchers in Wyoming, and Fox-Parrish (2002) studied citizens in Kansas. Each of these studies examined a limited population, but all suggested that urban residents were more favorably disposed toward prairie dogs than were rural residents. Zinn and Andelt (1999) suggested that those who had direct experience with prairie dogs 
were more likely to be knowledgeable about them than people who rarely see the animals. Although there would appear to be a measure of goodwill toward the rodents among urban residents and those who hold environmental values (FoxParrish, 2002; Zinn \& Andelt, 1999), the reservoir of positive attitudes seems small in rural communities (Reading et al., 1999; Wyoming Agricultural Statistical Service, 2001).

Preserving threatened and endangered species is one form of environmental protection, and Americans believe that protecting the environment is one of the most important issues (Greenberg Quinlan Research, Inc., 2000). "The most salient (environmental) issues are those that affect everyday quality of life and have immediate implications for health and safety of (peoples') families" (Greenberg Quinlan Research, Inc., 2000, p. 8). When environmental values affect quality of life, Americans have reported that they support "increased government involvement” (Greenberg Quinlan Research, Inc., 2000, p. 10; see also Cowie, 2001). But from the work of Zinn and Andelt (1999) we anticipated that prairie dogs would not constitute an everyday quality of life issue for most people and that we would find generally low levels of perceived environmental benefits from prairie dog management.

Zinn and Andelt (1999) reported that the general level of knowledge about prairie dogs was low but that people living near the animals had higher knowledge levels. Reading et al. (1999) found that rural residents had higher self-perceived knowledge. Pierce and Lovrich (1986) suggested that citizen knowledge about environmental issues presents a "technical information quandary" because people's knowledge is likely to be limited to one of three domains: Public, policy, or science. The quandary arises when the relative size of the public knowledge domain is small (Pierce \& Lovrich, 1986). Pierce and Lovrich (1986) suggested that a narrow public knowledge domain reduces the opportunity for meaningful public involvement in the policymaking process and limits interaction between citizens and natural resource managers. We expected to find that: (1) the public knowledge domain regarding prairie dogs would be relatively narrow and (2) respondents who found environmental issues harder to understand would have a lower level of knowledge.

According to Kellert (1993, p. 7), “...greater knowledge is often more of a basis for reinforcing and rationalizing attitudes than a cause for attitudinal convergence or change. Despite this qualification, one may assume knowledge exerts a moderately important influence on attitudes toward wildlife." Although Zinn and Andelt (1999) reported that increased knowledge was associated with more negative attitudes, we relied on Kellert (1993) by expecting that those with higher levels of term familiarity and general understanding of environmental issues would perceive more benefit from protecting prairie dogs.

The level of seriousness or salience of prairie dogs as an environmental problem should have a positive effect on knowledge and the benefits of prairie dog management. We expected that respondents who see the current status of 
prairie dogs as a serious environmental problem would be more likely to possess knowledge about the species. Because the issue is important to them, they should be more willing to make an effort to learn about prairie dogs and how to protect them. We also expected those who see the issue as serious to hold more positive views of the benefits of managing prairie dogs (Reading \& Kellert, 1993; Reading et al., 1999).

It is well documented that those who have more contact or direct experience with prairie dogs (e.g., frequency of sighting) have a higher level of perceived knowledge about the species (Reading, 1993; Reading \& Kellert, 1993; Zinn \& Andelt, 1999). People having more direct experience with prairie dogs include those in agricultural occupations such as farmers and ranchers. These people have been reported to be more likely to focus on the adverse effects of and need to control prairie dogs as opposed to valuing the species itself (Reading, 1993; Zinn \& Andelt, 1999). We expected a higher frequency of sighting the animal, agricultural occupation, and rural residence to be associated with lower perceived benefits from managing prairie dogs and more knowledge about the species.

The level of political activity aimed at influencing land use decisions should also be related to knowledge and the value of benefits from management. Miller, Pardo, and Niwa (1997) discussed the link between high levels of knowledge and political activity. They argued that there is a difference between the general public and what is known as the "attentive" public. The attentive public tends to be more knowledgeable about a particular subject, receives information through the print media, finds the subject more salient, and is more politically active (Miller et al., 1997). Thus, we expected higher levels of environmentally oriented political activity to be associated with higher levels of knowledge. We also expected respondents with higher levels of such political activity to have a more positive view of the benefits of managing prairie dogs.

According to Reading (1993), print media (e.g., books, articles, and magazines) and personal experience are among the sources of information that are important to farmers and ranchers. It was expected that increased use of both of these information sources would raise the level of knowledge about prairie dogs. However, the two variables were expected to have a different affect on perceptions of the benefits of prairie dog management. Whereas printed sources of information, such as scientific or technical media and government pamphlets, are more likely to contain some discussion of prairie dogs' importance to the prairie ecosystem, using other people and personal experience as sources are much more likely to reinforce existing negative attitudes (Long, 1998; Reading \& Kellert, 1993).

Value orientation is another important factor, which may be measured in terms of political ideology and environmentalism. We expected that a more conservative ideology would be associated with lower levels of knowledge and less beneficial perceptions of prairie dog management. Those who have a conservative political ideology may have less interest in environmental policy in general and 
prairie dogs in particular. With respect to perceptions, political conservatives have been reported to be less accepting of policy proposals coming from the environmental movement (Steel, List, \& Shindler, 1997). In contrast with ideology, we expected an environmentalist orientation to be positively associated with both knowledge and the benefits of managing prairie dogs (Shindler, List, \& Steel, 1993). Environmentalists are much more likely to view the situation facing prairie dogs as serious, have a better understanding of environmental issues, and make more of an effort to educate themselves concerning this issue. They should also have a more positive view of prairie dogs, be more likely to view the animals as important to the prairie ecosystem, and find benefits from managing the species (Graber \& France, 1998; Reading et al., 1999).

Finally, we expected that higher levels of formal education would be associated with higher levels of knowledge. According to Steel and his colleagues (1997), given the complexity of causes surrounding environmental issues, individuals with higher levels of education are more likely to have pro-environmental concerns. Therefore, we expected respondents with higher levels of education to be more knowledgeable and perceive greater benefits from managing prairie dogs than those with lower levels of education.

\section{Methods and Measurements}

Fourteen million people live in the 11 states of the short-grass prairie region where black-tailed prairie dogs occur. We surveyed citizens of that region during the summer of 2000. The study area was selected because it reflects the extent of black-tailed prairie dog historical distribution. The area included portions of the following states: Arizona, Colorado, Kansas, Montana, Nebraska, New Mexico, North Dakota, Oklahoma, South Dakota, Texas, and Wyoming. The results of two pretests were used to develop a mail-out survey instrument (OMB Control Number 1028-0073).

The sample was chosen by identifying addressees at random from each of 139 counties reported by USFWS to be within the historic range of black-tailed prairie dogs. Counties were selected at random from those categorized as rural, suburban, or urban using Cleland's Rurality Index (Cleland, 1995). A total of 46 rural, 50 suburban, and 43 urban counties were selected. Survey implementation followed Dillman's (1978) “Total Design Method." The response rate for the entire survey was $56 \%(n=1,933)$, with $53 \%(n=539)$ of respondents from urban, $56 \%(n=673)$ from suburban, and 60\% $(n=721)$ from rural counties.

\section{Dependent Variables}

Term familiarity. We followed the work of Pierce and Lovrich (1986) by using content analysis of black-tailed prairie dog conservation planning documents to identify technical terms for inclusion in this variable. An expert panel 
identified a list of terms ranging from widely known to generally unknown. This resulted in the selection of 11 terms. We recorded the percentage of people who said they knew or did not know the meaning of each term and then followed Pierce and Lovrich (1986) in assuming that terms with more than 66\% who knew the meaning constituted the public knowledge domain. Terms with fewer than $33 \%$ who knew the meaning constituted the science domain. To create the Term Familiarity variable, we summed each survey respondent's answer for the 11 terms. Respondents received a score of 1 if they reported "Knowing the meaning" and a 0 if they reported either "Heard of but don't know meaning" or "Have not heard of the term" (after Pierce, Steger, Steel, \& Lovrich, 1992). We used term familiarity as an independent variable in the Benefits of Managing Prairie Dogs model.

Benefits of managing prairie dogs. Respondents were asked about the four different management options: (1) protection on public and private lands; (2) protection on private lands with compensation; (3) protection on only public lands; and (4) no protection. Respondents rated these options on a 5-point scale with 1 being High Benefits to Society and 5 being Low Benefits to Society. The first three items were recoded to reflect a positive orientation toward the protection of prairie dogs. Scores range from 4 to 20.

\section{Independent Variables}

Knowledge. Whereas Term Familiarity looks at knowledge specific to prairie dogs, we also used a measure of general environmental knowledge. Respondents were asked if they found that "Environmental issues are hard to understand." Respondents rated this item using a 5-point scale. Higher scores indicate more difficulty in understanding environmental issues. Term Familiarity and understanding of environmental issues are both potential sources of variation in the perceived benefits of managing prairie dogs.

Interest factors. The level of interest shown by respondents concerning prairie dogs will likely affect both their level of knowledge and perception of benefits. We used two prairie dog-specific indicators, as well as a measure of overall involvement in land use decisions. The first of these is the perceived seriousness of the prairie dog problem. To measure this, respondents were asked the importance of deciding what to do about prairie dogs compared to other environmental problems in their state. Responses ranged from "One of the more serious environmental problems" to "It is not an issue at all." Higher scores reflect increased seriousness. The second is frequency of sighting. Respondents were asked how often they see prairie dogs per month: Scores were 0 (0 times), 1 (1 to 5 times), 2 (6 to 10 times), 3 (11 to 20 times), or 4 (More than 20 times). The third is level of political participation in land use decisions. The variable sums the Yes (1) and No (0) responses for 9 items ranging from attending a public hearing to helping organize 
a petition drive (Range of scores: 0 to 9 , with higher scores suggesting membership in the "attentive public" after Miller et al., 1997).

Sources of information. We used two variables to assess the effect of sources of information. The first was the use of printed sources of information to learn about prairie dogs. Printed sources include: scientific/technical media, general mailings to home, government pamphlets, and newspapers. Respondents indicating that they either used the source "Some" or "A Great Deal" received a 1. Responses of "None" and "Not Much" received a 0 (range 0 to 4 ).

The second variable was using people as a source of information. Respondents were asked how much they learned about prairie dogs from people. These included: friends and neighbors, public hearings, organizational meetings, county extension agents, and personal experience. Respondents indicating that they either used the source "Some" or "A Great Deal" received a 1. Responses of "None" and "Not Much" received a 0 (range 0 to 5).

Value orientation. Two different variables examined the effect of orientation on knowledge and perceptions of prairie dog management. First, to measure political ideology respondents were asked to indicate their orientation concerning environmental policy. The 7-point scale ranged from 1 (extremely liberal) to 7 (extremely conservative). Second, the New Environmental Paradigm (NEP) was used to measure environmentalist orientation. We followed Dunlap and Van Liere (1978) by using a series of five items to measure respondents' orientation toward the environment. Higher scores indicate that a respondent has a more environmentalist (i.e., ecocentric) as opposed to anthropocentric view of nature (after Pierce et al., 1992). Scores ranged from 5 to 25.

Sociodemographic characteristics. We examined three group-based social attributes. The first was level of formal education. Respondents were asked their highest level of education, which could range from 1 (No formal education) to 10 (An advanced degree). Another variable of group-based attributes was a respondent's current occupation. We focused on whether or not a respondent was employed in an agricultural job. Those who worked in agriculture were coded as 1 , otherwise 0 . The last sociodemographic characteristic was place of residence. The measure developed by Cleland (1995) to differentiate between urban, suburban, or rural residents was adapted so that higher scores indicated a more rural county of residence (Range of scores: 0 to 18).

\section{Methods of Analysis}

We used the Ordinary Least Squares (OLS) to examine the relationship between our variables of interest (term familiarity and perceptions of benefits) and independent variable. The independent variables included: sociodemographic, value orientation, interest factors, knowledge, and sources of information. 
Given our sample size $(n=1,933)$, we are aware of concerns about the potential effects of large sample size on statistics in OLS models. To check for these effects, we ran both of our OLS models using two separate random samples (with $n=$ approximately 400). We then compared coefficient scores among the three models and found that there was no significant difference among the models. This finding reduces concerns regarding large sample size impacts and supports use of unified OLS models.

\section{Findings}

\section{Univariate Results}

Most people were familiar with some terms often used in the management of prairie dogs. The items on the variable have a Cronbach's Alpha reliability coefficient of .8501, suggesting that respondents were mostly consistent in their response patterns. More than $80 \%$ of survey respondents said they knew the terms "burrowing" (90\%) and "Endangered Species Act" (85\%). Four terms were familiar to a majority of respondents: "urban sprawl" (68\%), "prairie ecosystem" (61\%), "habitat conservation" (54\%), and "biological vulnerability" $(54 \%)$. Three terms were familiar to approximately a third of respondents: "habitat fragmentation" (42\%), "Sylvatic Plague" (31\%), and "random demographic events" $(28 \%)$. The terms "diurnal" (16\%) and "extirpated" $(14 \%)$ were familiar to only a very few respondents (Table 1). Three terms (burrowing, Endangered Species Act, and urban sprawl) met the criterion for $66 \%$ or more who knew the

TABLE 1 Familiarity with Terms Related to Black-tailed Prairie Dog Management

\begin{tabular}{lccc}
\hline Term & $\begin{array}{c}\text { Know } \\
\text { meaning }\end{array}$ & $\begin{array}{c}\text { Heard of but don't } \\
\text { know meaning }\end{array}$ & $\begin{array}{c}\text { Don't know } \\
\text { meaning }\end{array}$ \\
\hline Burrowing & $90 \%$ & $5 \%$ & $5 \%$ \\
Endangered Species Act & $85 \%$ & $10 \%$ & $5 \%$ \\
Urban Sprawl & $68 \%$ & $10 \%$ & $22 \%$ \\
Prairie Ecosystem & $61 \%$ & $16 \%$ & $23 \%$ \\
Habitat conversion & $54 \%$ & $24 \%$ & $22 \%$ \\
Biological vulnerability & $54 \%$ & $22 \%$ & $25 \%$ \\
Habitat fragmentation & $42 \%$ & $25 \%$ & $34 \%$ \\
Sylvatic Plague & $31 \%$ & $21 \%$ & $49 \%$ \\
Random demographic events & $28 \%$ & $24 \%$ & $48 \%$ \\
Diurnal & $16 \%$ & $11 \%$ & $73 \%$ \\
Extirpated & $14 \%$ & $15 \%$ & $71 \%$ \\
\hline
\end{tabular}


TABLE 2 Level of Perceived Benefits Provided by Prairie Dog Management

\begin{tabular}{lcr}
\hline Level of benefits & $\begin{array}{c}\text { Number of } \\
\text { respondents }\end{array}$ & Percent \\
\hline Low (4-9) & 670 & 38 \\
Minimal (9-12) & 540 & 30 \\
Moderate (13-16) & 409 & 23 \\
High (17-20) & 160 & 9 \\
Totals & 1,779 & 100 \\
\hline
\end{tabular}

meaning and one term (prairie ecosystem) was very near that standard. Consequently, we concluded that four terms (36\%) constituted the public knowledge domain and four terms (Sylvatic Plague, random demographic events, diurnal, and extirpated) were in the science domain.

Of those terms familiar to at least half of respondents, all are found in common parlance, suggesting that well understood definitions provide a clue to the meaning in the context of prairie dog management. What seems to set these terms apart from those that were less-well known is that the less familiar terms are specific descriptors of technical aspects of wildlife management for which the terms themselves provide little access to the public. For example, the term random demographic events refers to a phenomenon that must be understood in its precise context; similarly, the terms Sylvatic Plague, diurnal, and extirpated are technical terms often used by field biologists but which are unlikely to be known by others (Table 1).

Respondents' perceptions concerning the social benefits of protecting prairie dogs were measured using the Benefits of Protecting Prairie Dogs variable. The Cronbach's Alpha reliability coefficient of .8011 for this variable suggests that respondents were mostly consistent in their response patterns for the additive scale and that scale components were intercorrelated. Table 2 shows the different levels of benefit that respondents believed would result from protecting prairie dogs. About twice as many respondents (68\%) reported that a "low" or "minimal" level of benefits would accrue from protecting prairie dogs than reported a "moderate" or "high" level of benefits (32\%). Thus, a sizable majority of respondents do not perceive increased protection of prairie dogs as making society better off.

\section{Multivariate Analyses}

Respondents' self-assessed knowledge concerning terms related to prairie dog management was measured by assessing term familiarity. Higher scores indicate 
a respondent was familiar with more terms. Table 3 shows the results of an OLS regression analysis of term familiarity. The model explains approximately $27 \%$ of the variance in respondents' familiarity with terms related to prairie dog management. The two random subsample models resulted in similar levels of explanation (26\% and 24\%) and similar Beta rankings (i.e., Political Participation and Education were highest ranked and Rurality, NEP, Seriousness of the Problem, and People as Sources of Information were the lowest ranked in all three models). A negative coefficient indicates that the higher the level of the independent variable the lower the respondent's overall term familiarity.

The model demonstrates the importance of several different types of variables in explaining the level of respondents' familiarity with terms. As expected, those who participated in more types of political activities $(\beta=.255, p<.001)$ and had higher levels of education $(\beta=.195, p<.001)$ believed they knew more terms, while those who professed a conservative political ideology with respect to environmental policy reported knowing fewer terms $(\beta=-.133, p<.001)$.

Sources of information, frequency of seeing prairie dogs, and general level of knowledge are factors that also provide an important part of the explanation concerning respondents' familiarity with terms. Those who learned more about prairie dogs using printed sources of information reported knowing more terms

TABLE 3 Ordinary Least Squares Model of Term Familiarity

\begin{tabular}{|c|c|c|c|c|c|}
\hline & $\begin{array}{l}\text { Unstandardized } \\
\text { coefficients (B) }\end{array}$ & $\begin{array}{l}\text { Standard } \\
\text { error (B) }\end{array}$ & $\begin{array}{c}\text { Standardized } \\
\text { coefficients } \\
\text { (Beta) }\end{array}$ & $t$ & Sig. \\
\hline Political participation & .392 & .039 & .255 & 10.077 & $<.001$ \\
\hline Education & .308 & .038 & .195 & 8.045 & $<.001$ \\
\hline Ideology & -.215 & .039 & -.133 & -5.554 & $<.001$ \\
\hline Printed sources & .423 & .089 & .124 & 4.754 & $<.001$ \\
\hline $\begin{array}{l}\text { Frequency of prairie } \\
\text { dog sightings }\end{array}$ & .207 & .050 & .104 & 4.111 & $<.001$ \\
\hline $\begin{array}{l}\text { Environmental issues } \\
\text { hard to understand }\end{array}$ & -.216 & .052 & -.098 & -4.155 & $<.001$ \\
\hline Agricultural job & .413 & .180 & .056 & 2.294 & .022 \\
\hline People as sources & .110 & .073 & .042 & 1.497 & .135 \\
\hline $\begin{array}{l}\text { New environmental } \\
\text { paradigm }\end{array}$ & -.018 & .015 & -.030 & -1.211 & .226 \\
\hline $\begin{array}{l}\text { Seriousness of } \\
\text { problem }\end{array}$ & -.087 & .076 & -.028 & -1.154 & .249 \\
\hline Rurality & -.005 & .015 & -.008 & -.309 & .757 \\
\hline
\end{tabular}

Adjusted $R^{2}=.267, F=47.587, p=<.001$. 
than respondents who were less reliant on these sources $(\beta=.124, p<.001)$. Respondents who said they often see the animals were more likely to say they knew terms $(\beta=.104, p<.001)$ while those who said "Environmental issues are hard to understand" reported they knew fewer terms $(\beta=-.098, p<.001)$.

Although less influential in the model, those employed in the agricultural sector also report knowing more terms than respondents from other occupations $(\beta=.056, p=.022)$. This is not surprising and may be related to the idea that increased exposure to prairie dogs - such as through working in agricultural jobs and frequency of sighting the animals-would be associated with more knowledge.

However, a measure somewhat related to exposure to the animals (i.e., people as sources of information) is not associated with knowledge of terms $(\beta=.042, p=.135)$. Also contrary to our expectations, environmentalist orientation (NEP; $\beta=-.030, p=.226)$, seriousness of the problem $(\beta=.028, p=.249)$, and rural residence $(\beta=-.008, p=.757)$ do not seem to be associated with knowledge of terms. Of these results, the most surprising is that rural residence is not a strong predictor in our model.

Ordinary least squares estimates for respondents' perceptions of the benefits of protecting prairie dogs are presented in Table 4. The model explains approximately $38 \%$ of the variance in the Benefits of Protecting Prairie Dogs variable. The two random subsample models resulted in similar levels of explanation (37\% and 39\%) and similar Beta rankings (i.e., Seriousness of the Problem, Frequency of Prairie Dog Sighting, and NEP were highest ranked while Rurality, Printed Information Sources, and Term Familiarity were ranked low in all three models). A positive coefficient suggests an increasing level of perceived benefit for protecting prairie dogs.

As in the Term Familiarity model, it is surprising that rural residence is not associated with benefits of prairie dog management $(\beta=-.041, p=.073)$. Also contrary to our expectations, term familiarity and printed sources of information are not associated with perceptions of benefits from prairie dog management $(\beta=-.028, p=.262)$.

Factors that do explain variation in the benefits of prairie dog management include seriousness of the problem $(\beta=.376, p<.001)$ and environmentalist orientation $(\beta=.196, p<.001)$. Respondents who identified themselves with an ecocentric view (i.e., the NEP; Dunlap \& Van Liere, 1978) were more likely to see protecting prairie dogs beneficially than those more closely identified with an anthropocentric view. People who viewed the problem of what to do with prairie dogs as serious were more likely to see the benefit of management. We expected the relationship between seriousness of the problem and benefits from management to be similar to that with frequency of seeing prairie dogs, holding agricultural occupations, and using people as sources of information. But unlike those who view managing prairie dogs as a serious problem, those who frequently see the animals $(\beta=-.183, p<.001)$, work in agriculture $(\beta=-.107, p<.001)$, or rely on 
TABLE 4 Ordinary Least Squares Model of the Benefits of Managing Prairie Dogs

\begin{tabular}{|c|c|c|c|c|c|}
\hline & $\begin{array}{l}\text { Unstandardized } \\
\text { coefficients (B) }\end{array}$ & $\begin{array}{l}\text { Standard } \\
\text { error (B) }\end{array}$ & $\begin{array}{c}\text { Standardized } \\
\text { coefficients } \\
\text { (Beta) }\end{array}$ & $t$ & Sig. \\
\hline $\begin{array}{c}\text { Seriousness of } \\
\text { problem }\end{array}$ & 1.760 & .106 & .376 & 16.601 & $<.001$ \\
\hline $\begin{array}{l}\text { New environmental } \\
\text { paradigm }\end{array}$ & .181 & .021 & .196 & 8.605 & $<.001$ \\
\hline $\begin{array}{l}\text { Frequency of prairie } \\
\text { dog sightings }\end{array}$ & -.549 & .071 & -.183 & -7.738 & $<.001$ \\
\hline Agricultural job & -1.191 & .253 & -.107 & -4.704 & $<.001$ \\
\hline People as sources & -.334 & .103 & -.084 & -3.250 & .001 \\
\hline Political participation & .195 & .057 & .084 & 3.443 & .001 \\
\hline $\begin{array}{l}\text { Environmental issues } \\
\text { hard to understand }\end{array}$ & -.242 & .073 & -.073 & -3.316 & .001 \\
\hline Ideology & -.138 & .055 & -.057 & -2.510 & .012 \\
\hline Education & .116 & .055 & .049 & 2.128 & .033 \\
\hline Rurality & -.037 & .021 & -.041 & -1.796 & .073 \\
\hline Term familiarity & -.042 & .038 & -.028 & -1.121 & 262 \\
\hline Printed sources & .134 & .126 & .026 & 1.064 & 287 \\
\hline
\end{tabular}

Adjusted $R^{2}=.379, F=71.020, p=<.001$.

people for information ( $\beta=-.084, p=.001)$ are less likely to see value from managing the species. This relationship is similar to those who found environmental issues hard to understand $(\beta=-.073, p=.001)$ or held a conservative political ideology related to the environment $(\beta=-.057, p=.001)$. As expected, respondents with higher levels of education and political participation were more likely to see the benefit from protecting prairie dogs than those less educated or politically active.

\section{Discussion}

What do people know about prairie dogs and their ecology and how does that knowledge relate to policy? Not surprisingly, respondents were more familiar with terms used in everyday conversation. They reported much lower levels of knowledge of more specific scientific and technical terms. All of this suggests that people may know something about general ecology, but when it comes to specifics about prairie dogs their knowledge cannot by any means be characterized as extensive. The public knowledge domain is relatively narrow (36\%) when 
compared with results reported in other studies that used the same method. For example, Pierce and Lovrich (1986) characterized the public domain as narrow when they found $40 \%$ of terms about instream flows in Idaho to be in the public domain and Lamb and Ponds (1999) reported 27\% of terms to be in the public domain regarding recreation management on the Colorado Plateau. On the other hand, Pierce and his colleagues (1992) found a much broader $60 \%$ of terms to be in the public domain concerning water quality issues.

This finding has important implications for public involvement in decisions concerning the management of prairie dogs. As Pierce and Lovrich (1986) observed, the ability of the general public to be involved in policy discussions depends, in part, on (1) the relative level of their knowledge compared to other actors (e.g., policymakers and experts) and (2) the extent to which information from the public domain is central to the resolution of the policy question. For example, a wider, more inclusive public domain would be expected to increase opportunities for the general public to be part of the policy discussion. However, given the limited understanding of technical terms concerning the management of prairie dogs, the policy discussion in this field is likely to be limited to experts and restrict the general public from interacting with managers (Pierce \& Lovrich, 1986).

This creates what Pierce and his colleagues $(1986,1992)$ described as the "technical information quandary" in democracy. That quandary is how to provide sufficient technical information to citizens to allow them to effectively participate in decision making. Lee (1993) suggested that this should be accomplished through "civic science": a form of inquiry in which scientists are more engaged with the public. Because the difficulties of prairie dog management are potentially intractable without shared knowledge, wildlife managers may wish to encourage scientists with specialized knowledge to participate in forums that emphasize direct experience. Such participation may help promote democratic decision making.

How are perceptions of prairie dogs related to quality of life considerations? Overall, citizens reported fairly negative perceptions of black-tailed prairie dog management. Just over two-thirds identified low to minimal benefits. Environmentalists (i.e., those identified with the NEP) and those who exhibited characteristics of the attentive public (i.e., increased seriousness of issue, higher level of political participation, understand environmental policy, and higher level of education) tended to see prairie dogs in a more favorable light. However, those who were in the best position to make a direct connection to quality of life-those who frequently saw, were in occupations that might bring them in contact with, or relied on friends and neighbors for information about prairie dogs - felt that protection of the rodents was less beneficial to society (Reading et al., 1999; Zinn \& Andelt, 1999).

Our findings suggest a challenge for wildlife managers. The most successful symbols of environmental concern are those directly relevant to an individual's quality of life or that evoke a fear of eminent ecological disaster (Greenberg 
Quinlin Research, Inc., 2000; Klineberg, McKeever, \& Rothenbach, 1998). Protection of prairie dogs does not rise to this level of public concern. The idea of these burrowing rodents as keystone species-which, if removed from the landscape, signal the collapse of an ecosystem - has not taken root in the perceptions of the general public. Prairie dogs seem to have achieved that status only with those predisposed toward a concern for the environment. Factors reflecting direct experience are associated with negative perceptions of the benefits of managing prairie dogs. This suggests that the problem for wildlife managers is difficult to resolve because scientific expertise about prairie dogs may be less important in public participation processes than experiential and anecdotal information (see McCool \& Guthrie, 2001).

Wildlife managers may take a couple of different approaches to more fully engage the public. They may have to find means to reduce the potential for harm that may be caused by existing populations of prairie dogs. For example, a program to compensate landowners for livestock losses due to prairie dog behavior might cast the rodents in a more positive light (Wyoming Agricultural Statistics Service, 2001). Alternatively, a program to protect the animals only on public lands where livestock use is curtailed might remove the immediate worry that private lands will be regulated. But programs of that type-while making the animals more acceptable to some-are unlikely to change the basic perception of prairie dogs as harmful among those who often see or live near them.

Because the general public tends to view prairie dogs as harmful, the issue of prairie dog protection is not perceived to be a major environmental concern. To reverse these negative perceptions, wildlife managers need to demonstrate how a keystone species is related to other environmental amenities and affects quality of life. That connection can probably be made only anecdotally. Wildlife managers may find it efficacious to provide experiential and anecdotal information via commonly used available print media, as well as outlets such as the Internet. Presenting scientific findings linked with experiential examples can help people connect prairie dog management with environmental benefits.

What is the link between knowledge and perceptions of benefits? Although a general understanding of environmental policy was associated with a positive view of prairie dogs, knowledge of terms was not. Although more information, better explained, might expand the public knowledge domain (see Pierce \& Lovrich, 1986), there is no guarantee that increased information will result in more positive public perceptions. Rather than changing people's attitudes, the chief benefit of increasing the breadth of the public knowledge domain may be in enhancing the quality of the public conversation over prairie dog management by "altering the structure of the debate, the relative power of individual actors, and the strategies they will choose" (Healy \& Ascher, 1995, p. 17). This suggests that wildlife managers can build a bridge to greater public involvement by helping people see personal consequences. This can be done if people recognize the animals in the wild, know how they live and the role they play in the ecosystem, have 
access to trusted sources of information about the problems they cause, and understand the range of viable management options. Further research on the relation between this species and quality of life would be a significant contribution to facilitating that level of understanding.

\section{References}

Barber, B. (2001). Prairie Dog Fight: Landowner Grants Stay of Eviction for Prairie Dogs. The Tulsa World, (29 July). Lexis-Nexis Academic Universe (Accessed 8-18-2001).

Black-tailed Prairie Dog Conservation Team. (2002). Update memorandum from Bob Luce, Interstate Coordinator to the Black-tailed Prairie Dog Conservation Team (February 20). Cheyenne, WY: Black-tailed Prairie Dog Conservation Team.

Center for Native Ecosystems. (2002). July 11, 2002: CNE Seeks Endangered Species Act Protection for White-tailed Prairie Dog. <http://www.nativeecosystems.org/press/ 020711.htm>. (Accessed 8-8-2002).

Cleland, C. L. (1995). Measuring rurality. Human Services in the Rural Environment, $18(4), 13-18$.

Cowie, R. (2001). Does the public care about species loss? Conservation Biology In Practice, 2(3), 26-27.

Dillman, D. A. (1978). Mail and telephone surveys: The total design method. New York: Wiley.

Dold, C. (1999). Friend or foe? Prairie dogs defended by ecology-minded, despised by ranchers. The Denver Post, (19 September 1999) F, 2.

Dunlap, R. E., \& Van Liere, K. D. (1978). The 'new environmental paradigm.' Journal of Environmental Education, 9(4), 10-19.

Fox-Parrish, L. (2002). Attitudes and opinions of landowners and general citizens relative to the black-tailed prairie dog. Masters thesis, Department of Biological Sciences, Emporia State University, Emporia, Kansas.

Gerhardt, G. (2000). 'Endangered' Prairie Dogs on Hold. Denver Rocky Mountain News, (4 February 2000), B, 1.

Graber, K., \& France, T. (1998). Petition for Rule Listing the Black-Tailed Prairie Dog as Threatened throughout its Range. National Wildlife Federation, petitioner to the U.S. Fish and Wildlife Service, Washington, DC.

Greenberg Quinlan Research, Inc. (2000). Environment top tier voting issue. Washington, DC: League of Conservation Voters, <www.1cvedfund.org/poll/index.html $>$. (Accessed 8-18-2001).

Healy, R. G., \& Ascher, W. (1995). Knowledge in the policy process: Incorporating new environmental information in natural resources policy making. Policy Sciences, 28, 1-19.

Hughes, J. (2000). Prairie dog gets a boost. Denver Post Online. <www.denverpost.com/ news/news0204c.html>. (Accessed: 2-4-2000).

Kellert, S. R. (1993). Attitudes, knowledge, and behavior toward wildlife among the industrial superpowers: United States, Japan, and Germany. Journal of Social Issues, $49,53-69$. 
Klineberg, S. L., McKeever, M., \& Rothenbach, B. (1998). Demographic predictors of environmental concern: It does make a difference how it's measured. Social Science Quarterly, 79(4), 734-753.

Kotliar, N. B., Baker, B. W., Whicker, A. D., \& Plumb, G. (1999). A critical review of assumptions about the prairie dog as a keystone species. Environmental Management, 24(2), 177-192.

Lamb, B. L., \& Ponds P. D. (1999). Citizen and opinion leader knowledge of natural resource management policy. Paper presented at the 60th Annual Conference of the American Society for Public Administration, Orlando, FL, April.

Lee, C. D., \& Henderson, R. (1989). Kansas attitudes on prairie dog control. Paper presented at Ninth Great Plains Wildlife Damage Control Workshop, Fort Collins, CO, April 18-20.

Lee, K. N. (1993). Compass and gyroscope: Integrating science and politics for the environment. Washington, DC: Island Press.

Long, M. E. (1998). The vanishing prairie dog. National Geographic, 193, 116-130.

Lybecker, D. L., Lamb, B. L., \& Ponds, P. D. (2002). Public attitudes and knowledge of the black-tailed prairie dog: A common and controversial species. BioScience, 52(7), 607-613.

McCool, S. F., \& Guthrie, K. (2001). Mapping the dimensions of successful public participation in messy natural resources management situations. Society and Natural Resources, 14(4), 309-323.

Miller, B. J., Reading, R. P., \& Forest, S. (1996). Prairie night: Black-footed ferrets and the recovery of endangered species. Washington, DC: Smithsonian Press.

Miller, J. D., Pardo, R., \& Niwa, F. (1997). Public perceptions of science and technology: A comparative study of the European Union, the United States, Japan, and Canada. Madrid: Fundacion BBV.

Pierce, J. C., \& Lovrich, N. P. (1986). Water resources, democracy and the technical information quandary. Millwood, NY: Associated Faculty Press, Inc.

Pierce, J. C., Lovrich, N. P., Tsurutani, T., \& Takematsu, A. (1989). Public knowledge and environmental politics in Japan and the United States. Boulder, CO: Westview Press.

Pierce, J. C., Steger, M., Steel, B., \& Lovrich, N. P. (1992). Citizens, political communication, and interest groups: A study of environmental organizations in Canada and the United States. New York: Praeger.

Reading, R. P. (1993). Toward an endangered species reintroduction paradigm: A case study of the black-footed ferret, Ph.D. Dissertation, Yale University, New Haven, CT.

Reading, R. P., \& Kellert, S. R. (1993). Attitudes toward a proposed reintroduction of black-footed ferrets (mustela nigripes). Conservation Biology, 7, 569-580.

Reading, R. P., Miller, B. J., \& Kellert, S. R. (1999). Values and attitudes toward prairie dogs. Anthrozoos, 12(1), 43-52.

Shindler, B., List, P. L., \& Steel, B. (1993). Managing federal forests: Public attitudes in Oregon and nationwide. Journal of Forestry, 9, 36-42.

Steel, B., List, P., \& Shindler, B. (1997). Managing federal forests: National and regional public orientations. In B. Steel (Ed.), Public lands management in the West: Citizens, interest groups, and values (pp. 17-32). Westport, CT: Praeger.

Van Pelt, W. E. (1999). The black-tailed prairie dog conservation assessment and strategy-Fifth draft. Nongame and endangered wildlife program. Arizona Game 
and Fish Department, Phoenix, Arizona, <http://www.r6.fws.gov/btprairiedog/conass strat.htm>. (Accessed 8-18-2001).

Wyoming Agricultural Statistics Service. (2001). Black-tailed prairie dog management survey: Report of results. Cheyenne, WY: Department of Game and Fish.

Zinn, H., \& Andelt, W. (1999). Attitudes of Fort Collins, Colorado residents toward prairie dogs. Wildlife Society Bulletin, 27(4), 1098-1106. 